\title{
Optimization of Ammonium Sulfate Concentration for Purification of Colorectal Cancer Vaccine Candidate Recombinant Protein GA733-FcK Isolated from Plants
}

\author{
Se-Ra Park, Chae-Yeon Lim, Deuk-Su Kim and Kisung Ko* \\ Therapeutic Protein Engineering Lab, Department of Medicine, College of Medicine, Chung-Ang University, Seoul, South \\ Korea
}

A protein purification procedure is required to obtain high-value recombinant injectable vaccine proteins produced in plants as a bioreactor. However, existing purification procedures for plant-derived recombinant proteins are often not optimized and are inefficient, with low recovery rates. In our previous study, we used 25-30\% ammonium sulfate to precipitate total soluble proteins (TSPs) in purification process for recombinant

OPEN ACCESS

Edited by: Basil J. Nikolau, lowa State University, USA

Reviewed by:

Vania Michelotti,

Consiglio per la Ricerca e la Sperimentazione in Agricoltura, Italy

Hyun-Soon Kim,

Korea Research Institute of Bioscience and Biotechnology, South Korea

*Correspondence: Kisung Ko ksko@cau.ac.kr

Specialty section:

This article was submitted to Technical Advances in Plant Science,

a section of the journal

Frontiers in Plant Science

Received: 14 August 2015 Accepted: 09 November 2015 Published: 27 November 2015

Citation:

Park S-R, Lim C-Y, Kim D-S and Ko K (2015) Optimization of Ammonium Sulfate Concentration for Purification of Colorectal Cancer Vaccine Candidate Recombinant Protein GA733-FCK Isolated from Plants.

Front. Plant Sci. 6:1040. doi: $10.3389 /$ fpls.2015.01040 proteins from plant leaf biomass which has not been optimized. Thus, the objective in this study is to optimize the conditions for plant-derived protein purification procedures. Various ammonium sulfate concentrations (15-80\%) were compared to determine their effects on TSPs yield. With 50\% ammonium sulfate, the yield of precipitated TSP was the highest, and that of the plant-derived colorectal cancer-specific surface glycoprotein GA733 fused to the Fc fragment of human lgG tagged with endoplasmic

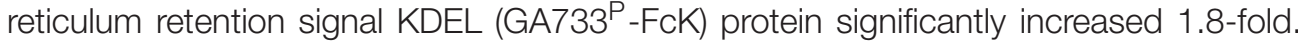
SDS-PAGE analysis showed that the purity of GA733 $\mathrm{P}$-FCK protein band appeared to be similar to that of an equal dose of mammalian-derived GA733-FC (GA733 ${ }^{\mathrm{M}}-\mathrm{FC}$ ). The binding activity of purified GA733P-FcK to anti-GA733 mAb was as efficient as the native $G A 733^{M}-F c$. Thus, the purification process was effectively optimized for obtaining a high yield of plant-derived antigenic protein with good quality. In conclusion, the purification recovery rate of large quantities of recombinant protein from plant expression systems can be enhanced via optimization of ammonium sulfate concentration during downstream processes, thereby offering a promising solution for production of recombinant GA733-Fc protein in plants.

Keywords: ammonium sulfate, colorectal cancer, GA733-Fc, recombinant vaccine, transgenic plant

\section{INTRODUCTION}

Mammalian, yeast, and insect cell cultures are used to produce recombinant subunit vaccines owing to their ability to express proteins in a manner similar to that observed in the native organism (Ko, 2014). However, expensive culture media and purification steps required for recovering recombinant proteins expressed in the cells of these organisms increase the cost of recombinant subunit vaccine production. In addition, most subunit vaccines produced in these systems are heat sensitive and require parenteral delivery, which restricts the use of recombinant subunit vaccines 
in many developing countries where health systems are not well equipped (Rigano and Walmsley, 2005). For use in plant molecular biofarming, the tobacco plant has several advantages over other plants, such as highly efficient transformation and regeneration, relatively short period for biomass production, and easy homogenization processing for protein purification due to soft leaf tissue (Jamal et al., 2009, 2012; Song et al., 2015). The tumor-associated antigen GA733, a glycoprotein that is highly expressed on the cell-surface of colorectal carcinomas, has previously been fused with the human immunoglobulin Fc fragment carrying the ER retention sequence, to produce the recombinant antigen-antibody complex GA733-FcK in a plant expression system (Lu et al., 2012; Park et al., 2015a,b). Moreover, expression of the recombinant protein GA733-FcK has been successful in a plant system (Lim et al., 2015). Optimization of the protein purification process is essential for the successful production of the tagged recombinant therapeutic protein in the total soluble protein (TSP) recovery step during the downstream process (Geyer et al., 2005; Aspelund and Glatz, 2010; Kim et al., 2015). To purify the tagged recombinant proteins, the TSPs must be extracted, separated, and eventually isolated, from the plant biomass debris (Desai et al., 2002). In general, 35\% ammonium sulfate is often applied for precipitation of TSPs from plant extracts (Lim et al., 2015). However, the ammonium sulfate concentration for the precipitation of TSPs harboring GA733-FcK has not been optimized. In this study, a recombinant colorectal cancer vaccine candidate fusion protein GA733-FcK expressed in transgenic Nicotiana tabacum plants was purified by protein-G affinity chromatography. Thus, we optimized ammonium sulfate TSP precipitation conditions to increase the recovery rate of GA733-FcK in transgenic plant leaves.

\section{MATERIALS AND METHODS}

\section{Plant Material}

Seedlings of transgenic tobacco ( $N$. tabacum) plants expressing the recombinant protein GA733-FcK ( $\mathrm{Lu}$ et al., 2012) were transplanted into a pot containing soil and grown in a greenhouse (Figure 1A).

\section{Removal of Chloroplasts}

For purification of the plant-derived recombinant protein GA733-FcK (GA733 ${ }^{\mathrm{P}}$-FcK), tobacco plant leaves were homogenized in an HR2094 blender (Philips, Seoul, Korea) using extraction buffer $(37.5 \mathrm{mM}$ Tris- $\mathrm{HCl}, \mathrm{pH} 7.5 ; 50 \mathrm{mM}$ $\mathrm{NaCl} ; 15 \mathrm{mM}$ EDTA; $75 \mathrm{mM}$ sodium citrate; and $0.2 \%$ sodium thiosulfate) (Figure 2). After centrifugation at $9,000 \times g$ for $30 \mathrm{~min}$ at $4^{\circ} \mathrm{C}$, the supernatant was filtered through a Miracloth (Biosciences, La Jolla, CA, USA), and $\mathrm{pH}$ of the filtered solution reduced to 5.1 by adding $99.0 \%$ ultrapure acetic acid, $\mathrm{pH} 2.4$. The solution was again centrifuged at $10,000 \times g$ for $30 \mathrm{~min}$ at $4^{\circ} \mathrm{C}$.

\section{Protein Precipitation}

After removal of the chloroplasts, the $\mathrm{pH}$ of the solution was brought up to 7.0 by adding $3 \mathrm{M}$ Tris- $\mathrm{HCl}$, and ammonium sulfate was added to $15 \%$ saturation at $4^{\circ} \mathrm{C}$ (Figure 2). After

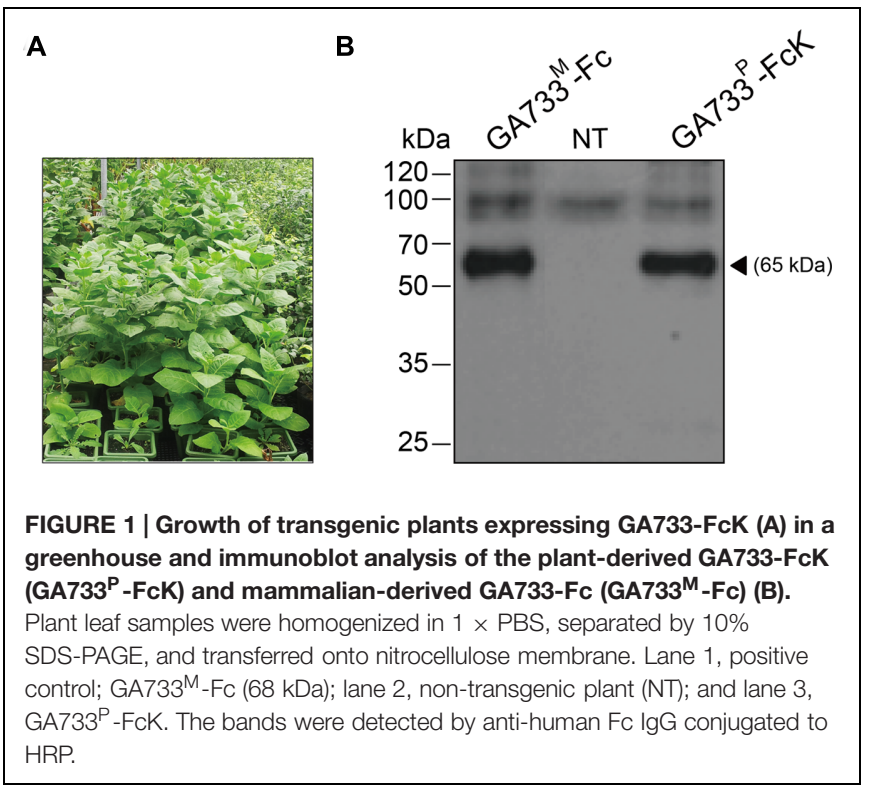

centrifugation at $9,000 \times g$ for $30 \mathrm{~min}$ at $4^{\circ} \mathrm{C}$, the supernatant was collected. Different concentrations $(15,20,30,40,50,60,70$, and $80 \%$ ) of ammonium sulfate were added to the supernatant at $4^{\circ} \mathrm{C}$. After incubation at $4^{\circ} \mathrm{C}$ overnight, the solution was centrifuged again at $9,000 \times g$. The pellet was resuspended in extraction buffer (1/10th of the original solution volume), and the final solution was then centrifuged at $10,000 \times g$ for $30 \mathrm{~min}$ at $4^{\circ} \mathrm{C}$. The supernatant of the extracted sample was then filtered through a $0.45 \mu \mathrm{m}$ filter (Merck Millipore, Darmstadt, Germany).

\section{Protein Elution}

The TSP solution was loaded onto a $1 \mathrm{ml}$ HiTrap protein G affinity column (Pharmacia, Uppsala, Sweden), and the column was washed with $10 \mathrm{~mL}$ binding buffer $(0.2 \mathrm{M}$ sodium phosphate, $\mathrm{pH}$ 7.0). After washing the column, the protein was eluted with elution buffer ( $1 \mathrm{M}$ glycin- $\mathrm{HCl}, \mathrm{pH}$ 2.7). One-milliliter aliquots of the fraction were collected in microtubes containing $55 \mu \mathrm{L}$ of neutralizing buffer (1 M Tris- $\mathrm{HCl}, \mathrm{pH} 9.0)$.

\section{Dialysis}

The eluted samples of $\mathrm{GA} 733^{\mathrm{P}}-\mathrm{FcK}$ were dialyzed against $1 \times$ PBS buffer $\left(137 \mathrm{mM} \mathrm{NaCl}, 10 \mathrm{mM} \mathrm{Na} \mathrm{HPO}_{4}, 2.7 \mathrm{mM}\right.$ $\mathrm{KCl}$, and $2 \mathrm{mM} \mathrm{KH}_{2} \mathrm{PO}_{4}$ ) twice at $4^{\circ} \mathrm{C}$ for $1 \mathrm{~h} 30 \mathrm{~min}$, and the final dialysis was performed overnight at $4^{\circ} \mathrm{C}$. Dialyzed samples were frozen in liquid nitrogen and stored at $-80^{\circ} \mathrm{C}$ until further analysis.

\section{SDS-PAGE}

Fresh harvested leaf samples $(100 \mathrm{mg})$ were ground in $300 \mu \mathrm{L}$ of $1 \times$ PBS buffer $\left(137 \mathrm{mM} \mathrm{NaCl}, 10 \mathrm{mM} \mathrm{Na}_{2} \mathrm{HPO}_{4}, 2.7 \mathrm{mM}\right.$ $\mathrm{KCl}$, and $\left.2 \mathrm{mM} \mathrm{KH}_{2} \mathrm{PO}_{4}\right)$. A $20 \mu \mathrm{L}$ sample was mixed with $4 \mu \mathrm{L}$ loading buffer (1 M Tris- $\mathrm{HCl}$, 50\% glycerol, 10\% SDS, 5\% 2-mercaptoethanol, and $0.1 \%$ bromophenol blue) and loaded onto the $12 \%$ protein gel. The proteins were electrophoresed using $1 \times$ SDS running buffer $(25 \mathrm{mM}$ Tris- $\mathrm{HCl}, 200 \mathrm{mM}$ glycine, 


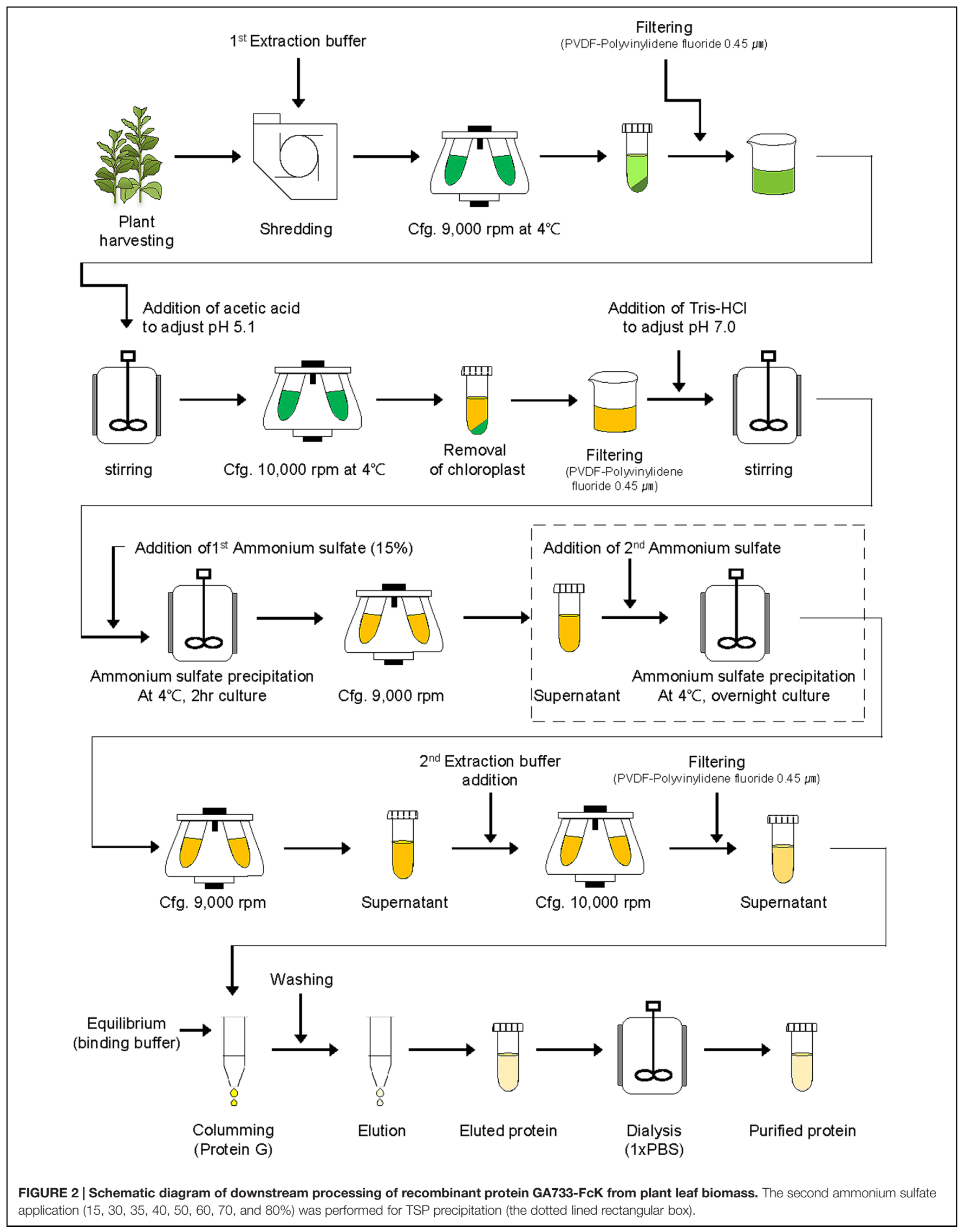




\section{A}

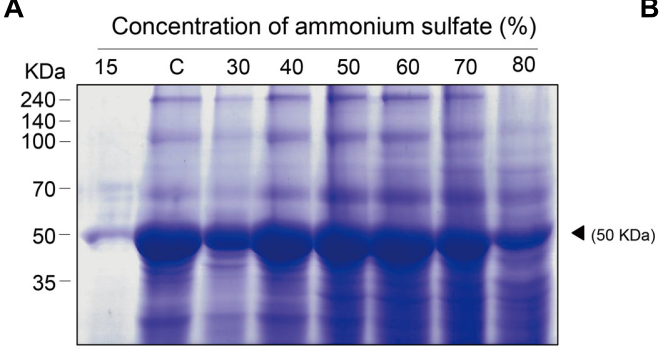

B

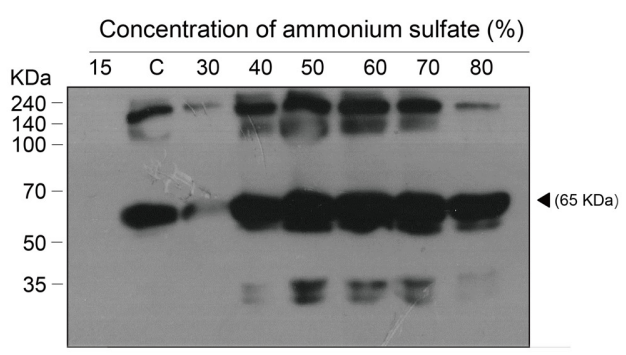

FIGURE 3 | SDS-PAGE to analyze the levels of TSPs precipitated from biomass extracts of transgenic plants expressing recombinant GA733-FcK (A) and western blot analysis to specifically detect recombinant GA733P-FcK in the precipitated TSPs (B). (A) TSPs were visualized on a Coomassie-stained SDS-PAGE gel. (B) GA733 P -FcK proteins were detected by anti-human Fc IgG conjugated to HRP. White and solid arrowheads indicate RuBisCO and GA733-FcK, respectively. C; 35\% ammonium sulfate used as a control.

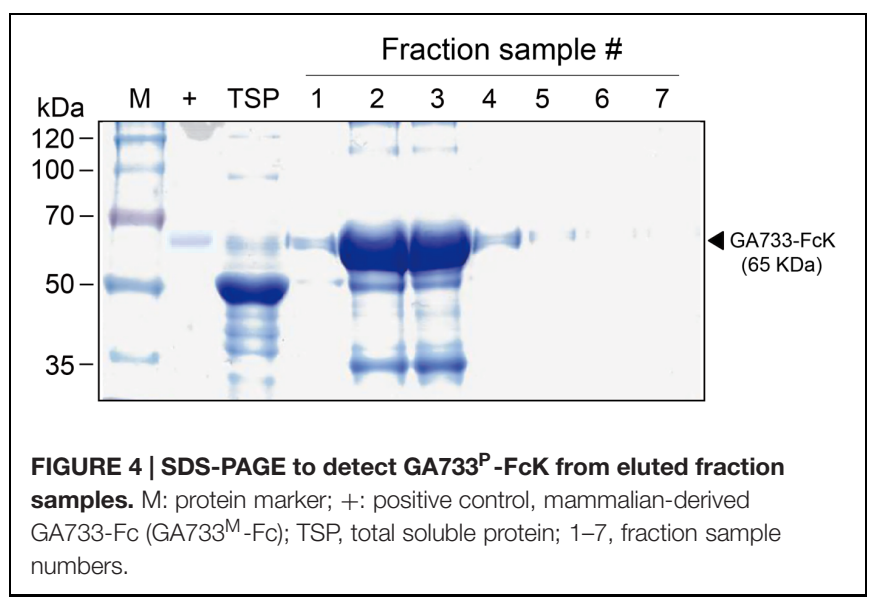

$0.1 \%[\mathrm{w} / \mathrm{v}] \mathrm{SDS})$. The protein gel was stained with Coomassie blue staining solution (10\% acetic acid [v/v], 30\% methanol [v/v], $0.01 \%$ Coomassie blue $[\mathrm{w} / \mathrm{v}]$ ) by shaking at room temperature (RT) for $30 \mathrm{~min}$. The gel was de-stained with $10 \%$ acetic acid by shaking at RT.

\section{Immunoblot Analysis}

The proteins electrophoresed through the gel were transferred to a nitrocellulose membrane (Millipore Corp., Billerica, MA, USA). Membranes were blocked with $5 \%$ skim milk powder (Sigma, St. Louis, MO, USA $)$ in $1 \times$ PBS-T buffer $(1 \times$ PBS plus $0.5 \%[\mathrm{v} / \mathrm{v}]$ Tween 20) at RT for $2 \mathrm{~h}$. The membrane was incubated for $1 \mathrm{~h}$ 30 min at RT with goat anti-human Fcy $(1: 15,000)$ recognizing the human Fc fragment portion of GA733-FcK. The protein bands were detected using SuperSignal chemiluminescence substrate (Pierce, Rockford, IL, USA). Protein bands were visualized by exposing the membrane to an X-ray film (Fuji, Tokyo, Japan) using a chemiluminescence substrate (Pierce).

\section{Surface Plasmon Resonance (SPR)}

Steady-state equilibrium binding of $\mathrm{GA} 733^{\mathrm{P}}-\mathrm{FcK}$ and $\mathrm{GA} 733^{\mathrm{M}}$ Fc were analyzed at $25^{\circ} \mathrm{C}$ using a ProteOn XPR36 surface plasmon resonance (SPR) biosensor (Bio-Rad Labs, Hercules,

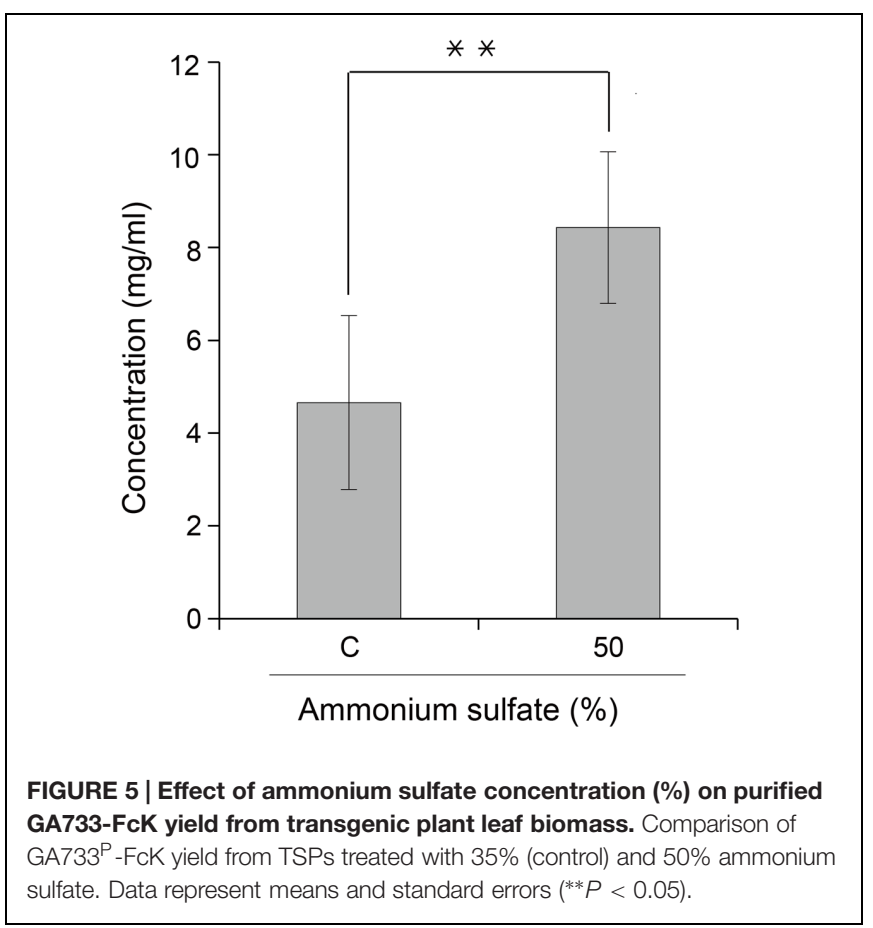

CA, USA) (Khurana et al., 2009; Kim et al., 2015). AntiGA733 mAb was injected for immobilization on the chip in the horizontal orientation of the ProteOn XPR36 fluidics at a flow rate of $40 \mu \mathrm{L} / \mathrm{min}$ for $90 \mathrm{~s}(60 \mu \mathrm{L})$. GA733 ${ }^{\mathrm{P}}-\mathrm{FcK}$ purified from plants $\left(1\right.$ and $2 \mu \mathrm{g}$ ) and $\mathrm{GA} 733^{\mathrm{M}}-\mathrm{Fc}(1$ and $2 \mu \mathrm{g})$ were injected in the vertical orientation of the ProteOn XPR36 fluidics for 6 min $(150 \mu \mathrm{L})$ at $25 \mu \mathrm{L} / \mathrm{min}$, allowing them to be captured by antiGA733 mAbs immobilized on the chip. The $1 \times$ SDS running buffer was injected simultaneously in the sixth channel to correct for loss of the captured supernatant $\mathrm{GA} 733^{\mathrm{P}}-\mathrm{FcK}$ or $\mathrm{GA} 733^{\mathrm{M}}-\mathrm{Fc}$ from the chip sensor surface during the experiment, as described by Nahshol et al. (2008). The data for binding kinetics of the anti-GA733 mAbs to both $\mathrm{GA} 733^{\mathrm{P}}-\mathrm{FcK}$ and $\mathrm{GA} 733^{\mathrm{M}}$-Fc were analyzed using Bio-Rad ProteON manager software. Affinity measurements were calculated using the Langmuir with Mass Transfer Algorithm (Khurana et al., 2009). 


\section{RESULTS}

\section{Expression of Recombinant GA733P-FcK Protein in Transgenic Plants}

The seedlings of transgenic plants expressing GA733-FcK (Lu et al., 2012) were transplanted into pots containing soil and grown in a greenhouse (Figure 1A). Western blot analysis with anti-human $\mathrm{Fc} \gamma$ antibody was conducted to confirm the expression of $\mathrm{GA} 733^{\mathrm{P}}$-FcK in the seedling leaf. GA733-FcK protein band was detected at approximately $65 \mathrm{kDa}$, similar to the band observed for GA733 ${ }^{\mathrm{M}}-\mathrm{FcK}$ (positive control) (Figure 1B). No band was observed in the non-transgenic plant (NT).

\section{Effect of the Second Ammonium Sulfate Concentration on TSP Precipitation}

Total soluble proteins isolated from transgenic plant leaf biomass and $\mathrm{GA} 733^{\mathrm{P}}-\mathrm{FcK}$ present therein were analyzed by SDSPAGE and western blot analyses, respectively (Figures 3A,B, respectively). In order to confirm the effect of the second ammonium sulfate concentration for TSP precipitation after homogenization of leaf biomass and removal of chloroplasts, the TSPs were precipitated using various concentrations (15$80 \%$ ) of the second ammonium sulfate (Figure 2, rectangle with a dotted line). TSP precipitation in the plant leaf extraction solutions was visualized on a Coomassie-stained gel. The levels of precipitated TSP in the extracts were the highest with $40-60 \%$ of ammonium sulfate (Figure 3A). At 15\%, the density of TSP bands was the weakest, followed by those at 80 and $30 \%$. The GA733 ${ }^{\mathrm{P}}$-FcK protein band in the TSP fraction was detected at approximately $65 \mathrm{kDa}$ by the secondary antibody anti-human Fc IgG conjugated to HRP at $30-80 \%$ ammonium sulfate, whereas no protein band was detected at $15 \%$ (Figure 3B). Among all the tested concentrations of ammonium sulfate, the density of $\mathrm{GA}_{733}{ }^{\mathrm{P}}$-FcK protein bands was stronger at 50, 60, and $70 \%$ ammonium sulfate than that at other concentrations $(15,30,40$, and 80\%) (Figure 3B).

\section{Effect of the Second Ammonium Sulfate Concentration on the Purified Recombinant Protein Yield}

GA733 ${ }^{\mathrm{P}}$-FcK purification was conducted using protein-G method. We confirmed and optimized the second ammonium sulfate concentration for a downstream procedure as above. Protein fraction samples after elution through protein $\mathrm{G}$ column were analyzed by Coomassie blue staining of SDS-PAGE (Figure 4). Fractions \# 2 and 3 showed strong protein band signals (Figure 4). The purified $\mathrm{GA} 733^{\mathrm{P}}-\mathrm{FcK}$ protein yield with different concentrations of the second ammonium sulfate was analyzed using SDS-PAGE and western blot. The purification yields of $\mathrm{GA} 733^{\mathrm{P}}-\mathrm{FcK}$ were compared between 35\% (control) and $50 \%$ of ammonium. The comparison results showed that the optimized concentration of the second ammonium sulfate application (50\%) showed 1.8-fold higher yield of GA733 ${ }^{\mathrm{P}}$-FcK compared to the control concentration (35\%) (Figure 5). The purity of GA733-FcK protein $(65 \mathrm{kDa})$ purified from plants was
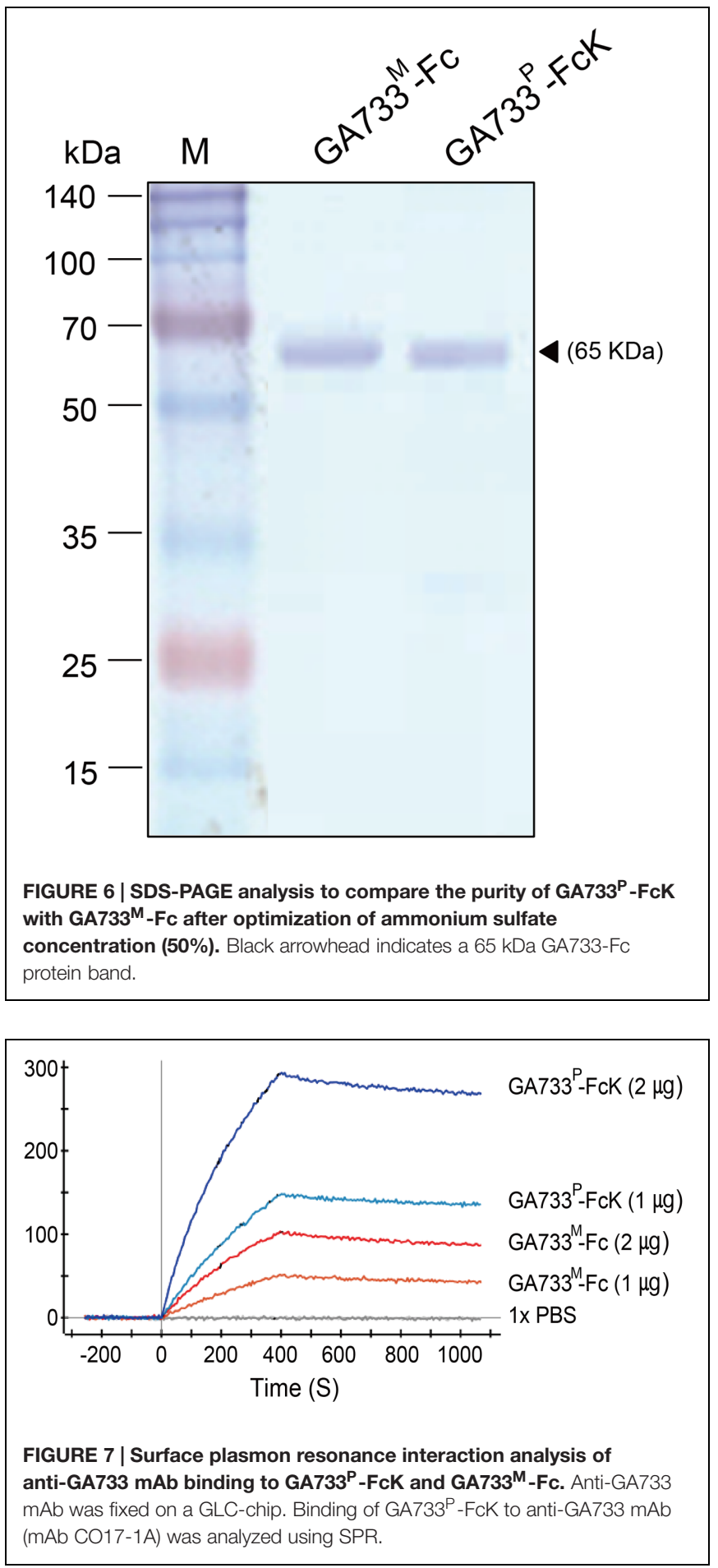

similar to the recombinant GA733-Fc protein $(65 \mathrm{kDa})$ purified from an animal expression system $\left(\mathrm{GA} 733^{\mathrm{M}}-\mathrm{Fc}\right.$ ) (Figure 6).

\section{Binding Activity of Purified GA733 ${ }^{P}$-FcK to Anti-GA733 mAb}

Kinetic analysis of binding activity of purified $\mathrm{GA} 733^{\mathrm{P}}-\mathrm{FcK}$ to anti-GA733 mAb using SPR showed that GA733 ${ }^{\mathrm{P}}$-FcK had 
almost three times higher $\mathrm{Ru}$ value than parental GA733 ${ }^{\mathrm{M}}-\mathrm{FcK}$. When the amount of $\mathrm{GA} 733^{\mathrm{P}}-\mathrm{FcK}$ and $\mathrm{GA} 733^{\mathrm{M}}$-Fc applied to the chip was doubled, the $\mathrm{Ru}$ values increased almost twice. A solution of $1 \times$ PBS as a negative control did not show any Ru value (Figure 7).

\section{DISCUSSION}

Plants used as expression systems for the production of recombinant therapeutic proteins are considered to have several advantages over other expression systems. These include low production cost of biomass containing recombinant proteins. However, the downstream process, including extraction and purification of the recombinant proteins from plant biomass, often is more complicated and expensive than other fermentation systems. Plant tissues contain a wide range of proteins with different properties, and these portions are subjected to extraction and purification during downstream processing. The non-optimized purification steps involved in recovering recombinant proteins expressed in plants increase the production cost of plant-derived proteins. However, existing purification procedures for these recombinant proteins have not been fully optimized ( $\mathrm{Lu}$ et al., 2012; Lim et al., 2015), and thus, are often inefficient, with low recovery rates (Park et al., 2015a).

The main purpose of this study was to optimize the conditions for precipitation of TSPs with the second ammonium sulfate application during the downstream purification process of the plant-derived GA733-FcK protein. Our data demonstrate the effects of ammonium sulfate concentration on TSP precipitation and the recovery rate of the $\mathrm{GA} 733^{\mathrm{P}}-\mathrm{FcK}$ from plant biomass. Western blot analysis was conducted to confirm the expression of GA733-FcK in the leaf biomass of transgenic plants grown in a greenhouse. GA733 ${ }^{\mathrm{P}}-\mathrm{FcK}$ was detected to be approximately $65 \mathrm{kDa}$ size, similar to the mammalian-derived $\mathrm{GA} 733^{\mathrm{M}}-\mathrm{Fc}$ (positive control) by the anti-human Fc IgG. GA733 ${ }^{\mathrm{P}}$-FcK yield with different concentrations of the second ammonium sulfate application was analyzed using SDS-PAGE and western blot.

\section{REFERENCES}

Aspelund, M. T., and Glatz, C. E. (2010). Purification of recombinant plant-made proteins from corn extracts by ultrafiltration. J. Membr. Sci. 353, 103-110. doi: 10.1016/j.memsci.2010.02.036

Desai, U. A., Sur, G., Daunert, S., Babbitt, R., and Li, Q. (2002). Expression and affinity purification of recombinant proteins from plants. Protein Express. Purif. 25, 195-202. doi: 10.1006/prep.2002.1627

Geyer, B. C., Muralidharan, M., Cherni, I., Doran, J., Fletcher, S. P., Evron, T., et al. (2005). Purification of transgenic plant-derived recombinant human acetylcholinesterase-R. Chem. Biol. Interact. 157-158, 331-334. doi: 10.1016/j.cbi.2005.10.097

Jamal, A., Ko, K., Kim, H.-S., Choo, Y.-K., Joung, H., and Ko, K. (2009). Role of genetic factors and environmental conditions in recombinant protein production for molecular farming. Biotech. Adv. 27, 914-923. doi: 10.1016/j.biotechadv.2009.07.004

Jamal, A., Lee, J.-H., Lee, K.-J., Oh, D.-B., Kim, D.-S., Lee, K.-K., et al. (2012). Chimerism of multiple monoclonal antibodies expressed in a single plant. Hort. Environ. Biotechnol. 53, 544-551.
We confirmed the level of precipitated TSPs in the extracts using SDS-PAGE. The highest levels of TSPs were observed when $40-60 \%$ ammonium sulfate was used. We verified that the TSP bands observed with 80 and $30 \%$ ammonium sulfate were weak, followed by that with $15 \%$. The $35 \%$ (control) application, which has been applied previously (Lu et al., 2012; Lee et al., 2013; Lim et al., 2015), showed similar band densities as those with $40-60 \%$ application. However, western blot analysis showed that the specific band density of GA733 ${ }^{\mathrm{P}}$ FcK detected by anti-human Fc IgG with 35\% application was lower than those detected with 40-60\%. These results suggest that the high TSP levels do not always indicate high levels of specific GA733-FcK in the TSPs. Indeed, at 30$80 \%$ concentration of ammonium sulfate, GA733-FcK protein band (at $\sim 65 \mathrm{kDa}$ ) was detected, whereas no protein band was detected with $15 \%$ ammonium sulfate application. The purification yields $(\mathrm{mg} / \mathrm{ml})$ of $\mathrm{GA} 733^{\mathrm{P}}-\mathrm{FcK}$ were compared between $35 \%$ (control) and 50\% of ammonium sulfate that resulted in the highest yields for TSPs and GA733-FcK proteins. The comparison results showed that after optimization (using 50\% ammonium sulfate), 1.8-fold higher yields were obtained compared to the control (35\%). Furthermore, the purity of GA733-FcK purified from plants was similar to that of the recombinant GA733-Fc protein purified from an animal expression system. These results suggest that purification recovery rate of large quantities of recombinant protein from transgenic plant expression systems can be enhanced via optimization of ammonium sulfate concentration during the downstream purification process, thereby offering a promising solution for the production of recombinant GA733-Fc protein in plant expression systems.

\section{ACKNOWLEDGMENTS}

This research was supported by a grant (Code\# PJ0111102015) from the Korean Rural Development Administration, National Research Foundation of Korea Grant funded by the Korean Government (MEST) (NRF-2014R1A2A1A11052922).

Khurana, S., Suguitan, A. L., Rivera, Y., Simmons, C. P., Lanzavecchia, A., Sallusto, F., et al. (2009). Antigenic fingerprinting of H5N1 avian influenza using convalescent sera and monoclonal antibodies reveals potential vaccine and diagnostic targets. PLoS ONE 6:e1000049. doi: 10.1371/journal.pmed.1000049

Kim, D.-S., Lu, Q., Lee, K.-J., and Ko, K. (2015). Optimization of colorectal cancer vaccine candidate protein GA733-Fc expression in a baculovirusinsect cell system. Entomol. Res. 45, 39-48. doi: 10.1111/1748-596 7.12092

Ko, K. (2014). Expression of recombinant vaccines and antibodies in plants. Monoclon. Antib. Immunodiagn. Immunother. 33, 192-198. doi: 10.1089/mab.2014.0049

Lee, J.-H., Park, D.-Y., Lee, K.-J., Kim, Y.-K., So, Y.-K., Ryu, J.-S., et al. (2013). Intracellular reprogramming of expression, glycosylation, and function of a plant-derived antiviral therapeutic monoclonal antibody. PLoS ONE 8:e68772. doi: 10.1371/journal.pone.00 68772

Lim, C.-Y., Lee, K.-J., Oh, D.-B., and Ko, K. (2015). Effect of the developmental stage and tissue position on the expression and glycosylation of recombinant 
glycoprotein GA733-FcK in transgenic plants. Front. Plant Sci. 5:778. doi: 10.3389/fpls.2014.00778.

Lu, Z., Lee, K.-J., Shao, Y., Lee, J.-H., So, Y. K., Choo, Y.-K., et al. (2012). Expression of GA733-Fc fusion protein as a vaccine candidate for colorectal cancer in transgenic plants. J. Biomed. Biotechnol. 12, 1-11. doi: 10.1155/2012/3 64240

Nahshol, O., Bronner, V., Notcovich, A., Rubrecht, L., Laune, D., and Bravman, T. (2008). Parallel kinetic analysis and affinity determination of hundreds of monoclonal antibodies using the ProteOn XPR36. Anal. Biochem. 383, 52-60. doi: 10.1016/j.ab.2008.08.017

Park, S. H., Kim, A. Y., Ma, S. H., Kim, H. M., Kang, H. S., Maeng, J. S., et al. (2015a). Purification of human carcinoma antigen GA733-2 expressed in Escherichia coli and production of its polyclonal antibody in rabbit. Anim. Cells Syst. 3, 188-193. doi: 10.1080/19768354.2015.1030345

Park, Y. S., Lee, J.-H., Park, J. Y., Hwang, H. S., Zenke, M., Han, D. W., et al. (2015b). Functionality of insect-cell-derived colorectal cancer vaccine candidate protein EpCAM-Fc in human dendritic cells. Entomol. Res. 45, 162-166. doi: 10.1111/1748-5967.12109
Rigano, M. M., and Walmsley, A. M. (2005). Expression systems and developments in plant-made vaccines. Immunol. Cell Biol. 83, 271-277. doi: 10.1111/j.14401711.2005.01336.x

Song, I., Kim, D. S., Kim, M. K., and Ko, K. (2015). Comparison of total soluble protein in various horticultural crops and evaluation of its quantification methods. Hort. Environ. Biotechnol. 56, 123-129. doi: 10.1007/s13580-0150097-y

Conflict of Interest Statement: The authors declare that the research was conducted in the absence of any commercial or financial relationships that could be construed as a potential conflict of interest.

Copyright $\odot 2015$ Park, Lim, Kim and Ko. This is an open-access article distributed under the terms of the Creative Commons Attribution License (CC BY). The use, distribution or reproduction in other forums is permitted, provided the original author(s) or licensor are credited and that the original publication in this journal is cited, in accordance with accepted academic practice. No use, distribution or reproduction is permitted which does not comply with these terms. 